\title{
EFFECT OF GLUCOSE INDUCTION ON BIOFILM DENSITY IN CLINICAL ISOLATE Acinetobacter baumannii PATIENTS IN INTENSIVE CARE UNIT OF DR. SOETOMO HOSPITAL, SURABAYA
}

\author{
Wira W. Lindarto, Eddy Bagus Wasito, Kartuti Debora \\ Department of Clinical Microbiology, Faculty of Medicine, Universitas Airlangga, Surabaya, Indonesia
}

\section{ABSTRACT}

This study aimed to analyze the effect of glucose induction on the clinical isolate biofilm density of Acinetobacter baumannii. Thirteen clinical isolates of A. baumannii non biofilm forming were collected from non-DM patients who were treated at the ICU of Dr. Soetomo Hospital, Surabaya, was treated with the addition of $0.08 \%$ glucose, $0.15 \%$ glucose, $0.2 \%$ glucose, and $0.4 \%$ glucose in TSB growth media, followed by biofilm density examination with Tissue Culture Plate Method (TCPM) using 96 wells flatbottomed polyesterene tissue culture plate and read by autoreader ELISA with a wavelength of 630 $\mathrm{nm}$ (OD630). Biofilm density obtained was analyzed using ANOVA statistical analysis. The results of OD630 showed that the biofilm density increased significantly at the addition of $0.2 \%$ and $0.4 \%$ glucose. There was a significant increase in biofilm density at the addition of $0.2 \%$ and $0.4 \%$ glucose so that the management of blood sugar levels in ICU patients was needed before and when medical devices were installed.

Keywords: Biofilm density; glucose; A. baumannii

\section{ABSTRAK}

Penelitian ini bertujuan untuk menganalisis pengaruh induksi glukosa terhadap kepadatan biofilm isolat klinis Acinetobacter baumannii. Tiga belas isolat klinis A. baumannii non biofilm dikumpulkan dari pasien non-DM yang dirawat di ICU Rumah Sakit Dr. Soetomo, Surabaya, dirawat dengan penambahan glukosa 0,08\%, glukosa 0,15\%, glukosa 0,15\%, dan 0,4\% glukosa dalam media pertumbuhan TSB, diikuti dengan pemeriksaan kerapatan biofilm dengan Metode Kultur Jaringan (TCPM) menggunakan 96 sumur plat kultur jaringan poliester flatbottomed dan dibaca oleh ELISA autoreader dengan panjang gelombang $630 \mathrm{~nm}$ (OD630). Kepadatan biofilm yang diperoleh dianalisis menggunakan analisis statistik ANOVA. Hasil OD630 menunjukkan bahwa kepadatan biofilm meningkat secara signifikan pada penambahan 0,2\% dan glukosa 0,4\%. Ada peningkatan yang signifikan dalam kepadatan biofilm dengan penambahan 0,2\% dan glukosa 0,4\% sehingga pengelolaan kadar gula darah pada pasien ICU diperlukan sebelum dan ketika peralatan medis dipasang.

Kata kunci: Densitas biofilm; glukosa; A. baumannii

Correspondence: Wira W. Lindarto, Clinical Microbiology Program, Faculty of Medicine, Universitas Airlangga, Surabaya, Indonesia. E-mail : wwiral77@yahoo.com

pISSN:2355-8393 • eISSN: 2599-056x • doi: http://dx.doi.org/10.20473/fmi.v56i2.21230

- Fol Med Indones. 2020;56:118-126 • Received 31 Dec $2018 \bullet$ Accepted 27 Jun 2019

- Open access under CC-BY-NC-SA license • Available at https://e-journal.unair.ac.id/FMI/

\section{INTRODUCTION}

Acinetobacter baumannii is a non-fermenting environmental flora Gram negative coccobasilus with the ability to colonize the human body. Acinetobacter baumanni is grouped by the Infectious Diseases Society of America as one of the six most important multidrugresistant (MDR) microorganisms found in hospital environments around the world (Talbot et al 2006). This bacterium is one of the pathogenic opportunistic bacteria which is responsible for $2-10 \%$ of the incidence of Gram negative bacterial infections in the hospital (Joly-Guillou, 2005).
Acinetobacter baumannii is currently recognized as a cause severe nosocomial infections, including skin and soft tissue infections, wound infections, urinary tract infections, and meningitis secondary (Bergogne-Bérézin \& Towner 1996, Towner 2009; Roca et al 2012, McConnell et al 2013) and have the highest mortality rates in cases of ventilator-associated pneumonia and blood stream infection (Dijkshoom et al 2007) where VAP has a crude mortality rate of around $40-70 \%$ (Fagon et al 1996, Garnacho-Montero et al 2003) while BSI has a crude mortality rate of around $28-43 \%$ (Seifert et al 1995, Wisplinghoff et al 2004). The 
incidence of A. baumannii infection is increased when associated with the length of time of hospitalization in hospital and in older patients (Wisplinghoff et al 1999).

Another thing that should be a concern of A. baumannii is the multi-drug resistance is caused by the intrinsic properties of its resistance against some classes of Blactam antibiotics and some other groups, and exacerbated by the misuse of broad-spectrum antibiotics. (Amyes \& Young 1996). A. baumannii have the capacity to develop resistance mechanisms against many classes of $\beta$-lactam antibiotics include a broad spectrum third generation cephalosporin, carboxypenicillins (Joly-Guillou et al 1995) and the class of carbapenems (Mussi et al 2005). A. baumannii is able to produce many enzymes that activate aminoglycoside groups (Buisson et al 1990, Lambert et al 1990) and most strains are resistant to the fluoroquinolone class (Joly-Guillou et al 1995, Vila et al 1993).

A. baumannii has the ability to survive in a hospital environment because it is able to interact with a variety of surfaces of both abiotic objects such as furniture, linen and medical devices (Neely et al 1999, Neely 2000, Villegas \& Hartstein 2003, Borer et al 2005) and biotics such as human epithelial cells or Candida albicans filaments (Lee et al 2006) and are able to form biofilms (Costerton et al 1999). There is a hypothesis that $A$. baumannii which survives in the hospital environment has primary virulence factors, namely multi-drug resistant properties and the ability to form biofilms. (Donlan \& Costerton 2002, Gaddy \& Actis 2009).

Biofilm formation often begins with colonization of bacteria on abiotic or biotic surfaces forming sessile microcolony and followed by the production of exogenous polysaccharide containing glycocalyx as a biofilm architectural structure. If environmental conditions do not support biofilms such as nutrient deficiencies or too many bacteria, the sessile organisms will freeze and become free-floating organisms, called planktonics, which will become pathogenic agents that cause infections associated with the installation of medical devices (Trautner \& Darouiche 2004) Based on the latest public report conducted by the National Institutes of Health, more than $60 \%$ of all microbial infections are caused by biofilms and often in recurrent infections or chronic infections, including nonresponsiveness to antibiotic therapy according to culture (Costerton et al 2003). Biofilms play an important role because they protect bacteria from antibiotic activity by changing the characteristics of bacterial cells and metabolic dormancy so as to cause resistance to antibiotics (Donlan 2002, Trautner \& Darouiche 2004).
Glucose has a very important role for the survival of bacteria, besides acting directly as a carbon source in the metabolic process, glucose is capable of acting as a signaling molecule and influencing the expression of various genes, one of which is a role in the biofilm formation process. A study of A. baumannii showed an increase in Bap protein production involved in the sugar utilization process through Leloir pathway, where high glucose levels will stimulate the anabolic process of glucose to UDP-glucose thereby increasing extracellular polysaccharide production in $A$. baumannii biofilms (Shin et al 2009, Cabral et al 2011). This study aims to analyze the effect of glucose induction on the formation of $A$. baumannii clinical isolates biofilms which have been isolated from patients admitted to the ICU of Dr. Soetomo Hospital, Surabaya.

\section{MATERIALS AND METHODS}

The study sample was a non-biofilm forming Acinetobacter baumannii clinical isolate from non-DM patients in the Intensive Care Unit of Dr. Soetomo Hospital, Surabaya, from April to May 2018. The study was conducted at the Clinical Microbiology Laboratory of Dr. Surabaya Soetomo and biofilm density readings were carried out at ITD Airlangga University Surabaya. The ethics committee of the Dr. Soetomo Hospital, Surabaya, has approved this research as outlined in the ethics feasibility statement number 0213/KEPK/IV/ 2018 .

\section{Laboratory procedures}

Clinical specimens from patients were inoculated on growth media and incubated for 24 hours. Identification with Gram staining taken from colonies in primary culture and continued identification using the BD Phoenix 100 system automatic method. Isolates were examined for detection of biofilms using Microtiter Plate Methode (MTPM) and the results were negative biofilm production. Isolates are stored in the $-800 \mathrm{C}$ freezer until the glucose induction process is carried out.

\section{Biofilm density assay using microtiter plate method (MTPM)}

Each flat-bottomed microtiter plate well 96 polystyrene tissue culture-treated microtiter plate was filled with $180 \mu \mathrm{l}$ TSB and $20 \mu \mathrm{l}$ of 0.5 McFarland bacterial suspension and as a negative control contained $180 \mu \mathrm{l}$ TSB. To examine the effect of glucose induction on the biofilm density, we successively added glucose concentrations of $0.08 \%, 0.15 \%, 0.2 \%$ and $0.4 \%$ in TSB. Next the plate is closed and incubated at 350C for 24 hours. After incubation, the contents of the well were removed 
and then washed with $300 \mu$ l phosphate buffer saline $(\mathrm{pH}$ 7.2) three times and dried in the inverted position.

Each well was filled with $150 \mu$ methanol $100 \%$ for 20 minutes so that the biofilm produced by the bacteria will be fixed on the base and wall of the well. The microtiter plate was emptied by tapping and left in the inverted position then the biofilm was stained with crystal violet $(0.1 \%)$ for 5 minutes. The remaining excess crystal violet is washed with deionized water and the plate is dried. Dried crystal violet on surface of each well diluted with $200 \mu \mathrm{l}$ ethanol $100 \%$ for 30 minutes and continued for reading process.

Biofilm density which is bound to the base and wall of the microtiter plate well is read using ELISA reader with a wavelength of $630 \mathrm{~nm}$, expressed as an Optical Density (OD630) value. These OD values are considered as indices of bacterial attachment to the surface of microtiter plate wells and forming biofilms. The interpretation of biofilm density is: 1 . Negative if OD630 < $0.275 ; 2$. Low if $0.275<$ OD630 < $0.55 ; 3$. Moderate if $0.55<$ OD630 $<0.825$; and 4. High if
OD630 $>0.825$. Data analysis was performed to assess the effect of glucose induction on the biofilm density by ANOVA method using statistical significance level ( $p$ value $<0.05)$.

\section{RESULTS}

Thirteen clinical isolates of A. baumannii induced with concentration of glucose successively $0 \%, 0.08 \%$, $0.15 \%, 0.2 \%$ and $0.4 \%$ respectively. Biofilm density checks were carried out using the iMark Bio Rad tool. Microplate Reader with a wavelength of $630 \mathrm{~nm}$ gives the average biofilm density results successively $0.126+$ $0.062 ; 0.137+0.042 ; 0.272+0.124 ; 1,274+0,290$; $3,407+0,269$.

Statistical analysis of the effect of glucose induction on A. baumannii biofilm density using SPSS 17.0 with the same subject ANOVA method $(\mathrm{p}<0.05)$ showed a significant effect of glucose induction on biofilm density in clinical isolates of A. baumannii non-biofilm forming.

Table 1. Results of reading optical density with a wavelength of 630nm (OD630) samples of A. baumannii before and after the addition of glucose

\begin{tabular}{cccccc}
\hline Samples & No GLU & GLU 0.08\% & GLU 0.15\% & GLU 0.2\% & GLU 0.4\% \\
\hline A. baumannii-001 & 0.132 & 0.119 & 0.177 & 0.870 & 3.269 \\
A. baumannii-002 & 0.144 & 0.125 & 0.177 & 0.902 & 3.330 \\
A. baumannii-003 & 0.058 & 0.112 & 0.480 & 1.412 & 3.455 \\
A. baumannii-004 & 0.061 & 0.139 & 0.228 & 1.296 & 3.620 \\
A. baumannii-005 & 0.075 & 0.133 & 0.211 & 1.206 & 3.536 \\
A. baumannii-006 & 0.236 & 0.103 & 0.168 & 1.006 & 3.434 \\
A. baumannii-007 & 0.199 & 0.096 & 0.224 & 1.385 & 3.387 \\
A. baumannii-008 & 0.079 & 0.254 & 0.169 & 1.323 & 3.672 \\
A. baumannii-009 & 0.148 & 0.166 & 0.423 & 1.519 & 3.675 \\
A. baumannii-010 & 0.062 & 0.158 & 0.470 & 1.595 & 3.684 \\
A. baumannii-011 & 0.216 & 0.140 & 0.394 & 1.870 & 3.416 \\
A. baumannii-012 & 0.145 & 0.088 & 0.144 & 1.012 & 2.735 \\
A. baumannii-013 & 0.085 & 0.145 & 0.268 & 1.173 & 3.076 \\
\hline Mean & 0.126 & 0.137 & 0.272 & 1.274 & 3.407 \\
\hline
\end{tabular}

Table 2. Descriptive statistic data

\begin{tabular}{cccc}
\hline Glucose Induction & Mean & Std. Deviation & Total Samples \\
\hline $0 \%$ & 0.126 & 0.062 & 13 \\
$0.08 \%$ & 0.137 & 0.042 & 13 \\
$0.15 \%$ & 0.272 & 0.124 & 13 \\
$0.20 \%$ & 1.274 & 0.290 & 13 \\
$0.40 \%$ & 3.407 & 0.269 & 13 \\
\hline
\end{tabular}


Table 3. Double comparison data of influence of glucose concentration on biofilm density

\begin{tabular}{lccccc}
\hline & $\begin{array}{c}\text { Without } \\
\text { Glucose } \\
\text { Induction }\end{array}$ & $\begin{array}{c}\text { Glucose } \\
\text { Induction } \\
0.08 \%\end{array}$ & $\begin{array}{c}\text { Glucose } \\
\text { Induction } \\
0.15 \%\end{array}$ & $\begin{array}{c}\text { Glucose } \\
\text { Induction } \\
0.2 \%\end{array}$ & $\begin{array}{c}\text { Glucose } \\
\text { Induction } \\
0.4 \%\end{array}$ \\
\hline $\begin{array}{l}\text { Without Glucose } \\
\text { Induction }\end{array}$ & - & 0.671 & 0.005 & $<0.0001$ & $<0.0001$ \\
$\begin{array}{l}\text { Glucose Induction } \\
0.08 \%\end{array}$ & - & - & 0.002 & $<0.0001$ & $<0.0001$ \\
$\begin{array}{l}\text { Glucose Induction } \\
0.15 \%\end{array}$ & - & - & - & $<0.0001$ & $<0.0001$ \\
$\begin{array}{l}\text { Glucose Induction } \\
0.2 \%\end{array}$ & - & - & - & - & $<0.0001$ \\
\hline ANOVA statistical analysis $\mathrm{p}=0.000(\mathrm{p}<0.05)$ & & & &
\end{tabular}

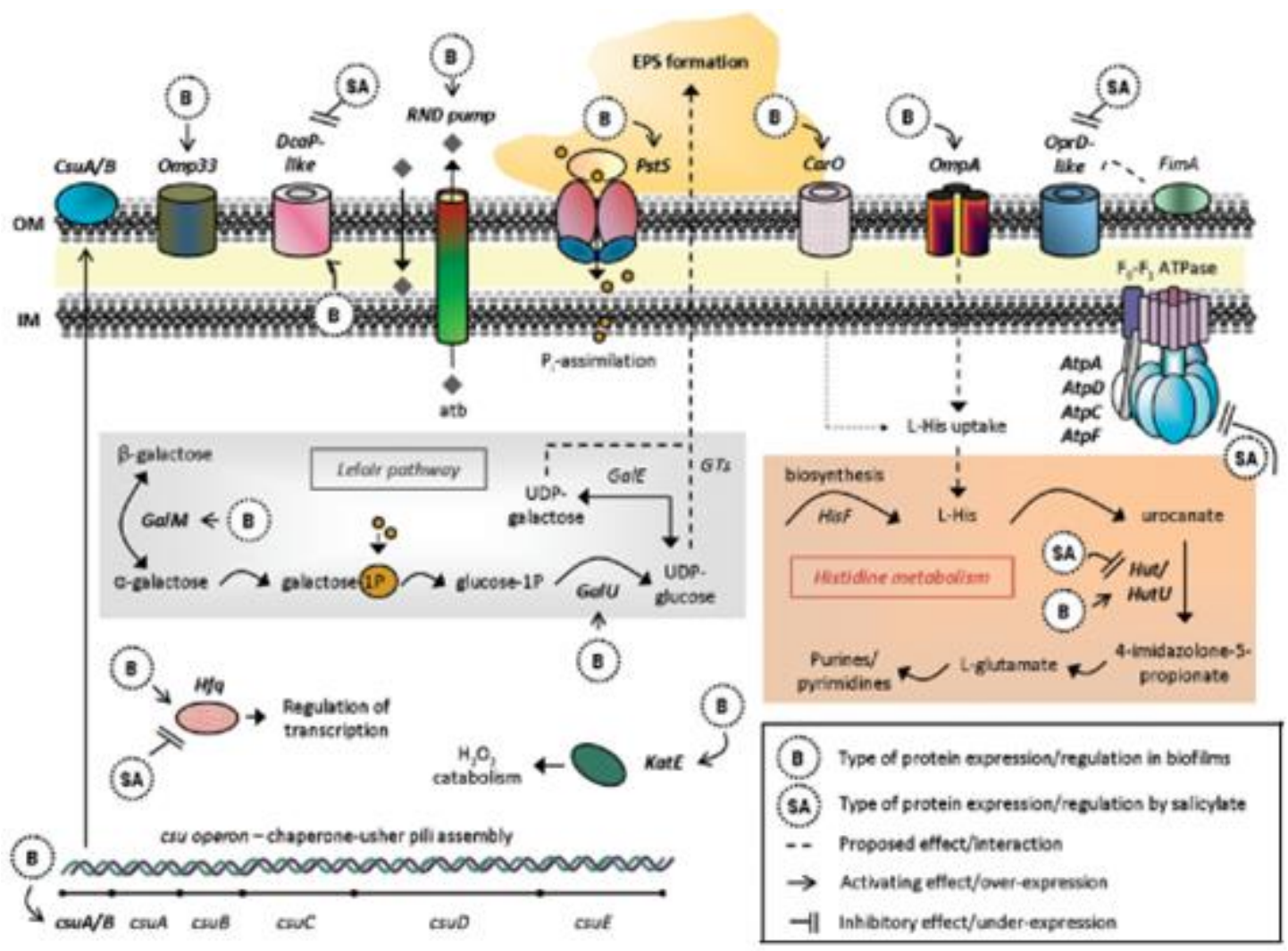

Fig. 1. Leloir pathway (Cabral et al 2011).

\section{DISCUSSION}

Acinetobacter baumannii is a Gram negative coccobasil bacteria that is facultative anaerobic, pleomorphic and non-motile has become one of the bacteria that is often found in patients who are hospitalized and cause various types of infections in patients in hospitals, including pneumonia, tract infections urinary, bacteriemic, wound infection, meningitis and Ventilator-Associated Pneumonia (VAP) (Safari et al 2015, Vijayakumar et al 2016).

A 5-year retrospective study conducted at the University of Maryland Medical Center showed that $4 \%$ of the total 7925 patients underwent A. baumannii MDR colonization in the perianal region and had a profile including 
the elderly ( $>50$ years), patients had received previous antimicrobial therapy and has been admitted to an Inpatient Installation for 2 days or more. In these patients it is 15.2 times more likely to experience an $A$. baumannii MDR infection as evidenced by positive culture results, and has a 1.4 times higher risk of dying during ICU care. A. baumannii MDR colonization can develop into an infectious process in ICU-treated patients because of the use of assistive devices including intravenous catheter installation, urine catheter, nasogastric tube insertion and mechanical ventilator use; and the condition of patients who are immunocompremised and sanitary hygiene are poorly maintained (Blanco et al 2018).

Biofilm is one of the virulence factors of A. baumannii which often complicates management of infection and A. baumannii MDR therapy which worsens the condition and prognosis of patients admitted to hospitals in general and those who are admitted to ICU in particular (Longo et al 2014, Badave \& Dhananjay 2015). The National Institutes of Health reports that more than $60 \%$ of microbial infections are caused by biofilms and frequent chronic infections are repeated and are often irresponsive to antimicrobial therapy (Costerton et al 2003).

In this study, using clinical isolates of A. baumannii non-biofilm forming obtained from 13 non-DM patients who were admitted to the ICU dr. Soetomo Surabaya in the period April-May 2018. Most isolates were from non-DM patients who were admitted to the Intensive Care Unit with the age group 30-39 years and 60-69 years (each of 4 patients or $30.8 \%$ ) and the group age of 40-49 years as many as 2 patients (15.4\%). The age group> 40 years has risk factors for experiencing metabolic disorders, hemodynamic disorders or malignant processes that often require treatment in the ICU. In ICU care, patients are often attached to medical devices for therapeutic or diagnostic purposes such as intravenous lines, urine catheters, naso-gastric tubes or mechanical ventilators. This will increase the potential translocation of colonized A. baumannii MDR, both in patients and in the environment around the patient, thus triggering the process of $A$. baumannii MDR infection. This will be exacerbated in immunocompremised conditions in patients and poor maintenance of sanitation of patients and the surrounding environment (Khosama 2015, Haryani et al 2016, Arisma et al 2017).

According to the antimicrobial resistance, the sample consisted of $76.92 \%$ MDR A. baumannii and $23.08 \%$ non-MDR. This is consistent with the picture of an increase in the incidence of $A$. baumannii MDR infection in Southeast Asia up to $40-67 \%$ (Hsu et al 2017) and shows the risk factors for A. baumannii MDR infection in patients admitted to the ICU (Yanong et al 2017, Anandhalakshmi et al 2017, Blanco et al 2018).

Based on the type of clinical isolate specimens obtained, 8 of 13 specimens $(61.53 \%)$ were sputum aspirates from ETTs installed in patients treated in the ICU and 2 specimens $(15.38 \%)$ were from blood specimens. This supports the fact that $A$. baumannii MDR is often a pathogen associated with the risk of VentilatorAssociated Pneumonia (VAP) in ICU-treated patients (Sukanya et al 2014, Anandhalakshmi et al 2017). The adhesion ability of $A$. baumannii on the surface of abiotic objects, in this case is the surface of EndoTracheal Tube, and on the surface of host respiratory epithelial cells to be virulence factors for these bacteria to colonize to trigger the infection process in the host (Lee et al 2007, Giannouli et al 2013). The overexpression of genes involved in the process of biofilm formation in $A$. baumannii, including chaperone-usher type I pili assembly system, OmpA, poly- $-(1,6)-\mathrm{N}$ acetyl glucosamine (PNAG), Biofilm associated protein (BAP), triggers the production of A. baumannii biofilm which colonizes the surface of the ETT pipe and the surface of host respiratory epithelial cells, making it a source of chronic and recurrent infections (Zarrilli 2016).

This study showed a significant increase in biofilm production from A. baumannii non-biofilm forming clinical isolates treated with the addition of glucose with a certain concentration. In table 1 , it can be seen that the results of reading Optical Densitry $630 \mathrm{~nm}$ (OD630) on TSB media without the addition of glucose inoculated with 0.5 McFarland $A$. baumannii showed no biofilm formation $(\mathrm{OD}<0.275)$. The formation of biofilms has not been seen in $A$. baumannii bacteria which was dinoculated in TSB media which added $0.08 \%$ glucose and $0.15 \%$ glucose. The formation of biofilms began to appear significantly in TSB media which added $0.2 \%$ glucose and increased even more at $0.4 \%$ glucose.

Addition of glucose with a concentration of $0.08 \%$, $0.15 \%, 0.2 \%$ and $0.4 \%$ aimed at bacteria living in an atmosphere of the same blood sugar levels in patients. Glucose concentration is $0.08 \%$ to represent the condition of patients with normal fasting blood sugar level $(80 \mathrm{mg} / \mathrm{dL})$, while $0.15 \%$ glucose concentration represents the condition of patients with normal blood sugar level 2 hours post prandial $(150 \mathrm{mg} / \mathrm{dL})$. Addition of a concentration of $0.2 \%$ was representative of the condition of the blood sugar level which was slightly higher than the normoglycemic condition $(0.08-0.15 \%)$ but in borderline hyperglycemic conditions in DM patients $(200 \mathrm{mg} / \mathrm{dL}) . \quad 0.4 \%$ glucose addition represented a high level of patient's blood sugar level (400 mg/dL) (NICE Guiedelines). 
The results of this study support the results of a similar study conducted at the RSUD dr. Soetomo Surabaya in 2017 about the effect of glucose induction on E. coli biofilm formation obtained from indwelling urine catheters. In this study showed a positive correlation between increased glucose concentration in the environment around bacteria and increased biofilm formation (Mewo 2017).

A. baumannii is not able to ferment glucose and is unable to use glucose as a carbon source or a single energy source (Kitagawa et al 1986), but this bacterium has NADH dehydrogenase (Ubiquinone), an enzyme that functions to react dehydrogenase to glucose, to produce ATP which is used as energy in the active transport system (van Schie et al 1985, Kitagawa et al 1986) and biosynthetic processes (Towner et al 1991). Glucose can function as an important carbon source for bacteria and can act as a signaling molecule that will affect the expression of various genes including those directly involved in glucose utilization. The growth of A. baumannii in a glucose-enriched medium will increase the bacterial sugar anabolism process so that it will trigger an increase in lipopolysaccharide biosynthesis and exopolysaccharide, so that an increase in exogenous glucose triggers the emergence of inflammatory cytokines from host macrophages and increases the bacterial hemolytic activity. Both of these allow the pathogenesis of $A$. baumannii to occur during sepsis conditions (Rossi et al 2016).

Rossi et al's study of the effect of glucose on lipopolysaccharide production and immunogenicity in A. baumannii showed a decrease in bacterial growth in the exponential phase in glucose-enriched media. This shows that A. baumannii is able to use glucose as a carbon source but is less effective (Rossi et al 2016). In the same study, transcriptomic analysis showed an increase in the expression of genes involved in primary metabolism, such as energy production (especially NADH: ubiquinone reductase multisubunit system), transcription and translation processes and cell wall biogenesis, which usually occur in the cell replication process exponential phase on the bacterial growth curve (Cox 2004). Based on these two things, it can be concluded that there is a process of other metabolic activities that occur in these glucose-rich conditions.

In the transcriptomic analysis of the above study, there was a downregulation of the NDP-sugar epimerase gene, which involved the biogenesis of outer membranes from bacterial cell walls, accompanied by upregulation of murG, pgm and galM and galU genes. The murG gene produces the main enzyme to combine sugar into peptidoglycan. The pgm gene produces the phosphoglucomutase enzyme as a catalyst for the isomerization process of sugar-6-P into sugar-1-P which is the first step in the biosynthesis process of energyactivated sugars in the EPS production process. Cabral et al argue that the galM gene encodes the galactose-1epimerase enzyme and the galU gene encodes the UTPglucose-1-P uridylyltransferase enzyme, wherein the Leloir pathway is involved in galactose utilization, which is associated with precrusor EPS biosynthesis in several bacteria including $A$. baumannii by process glycosyltransferase (Cabral et al 2011).

Shin et al stated proteins that are only expressed in biofilm producing cells are UDP galactose 4-epimerase (GalE), ProFAR isomerase (HisA) and GidA (Shin et al 2009). The role of the GalE protein (UDP-galactose 4epimerase) in the Leloir pathway which functions the conversion of UDP-galactose to UDP-glucose and vice versa, which is used as the basic framework of bacterial EPS in general (Whitfield \& Paiment, 2003). The HisA protein in the form of ProFAR isomerase involved in the process of histidine biosynthesis which plays an important role both in purine synthesis and nitrogen metabolism (Fani et al 2007). GidA protein has the role of repairing DNA by controlling the translation process through modification of tRNA if there is a misreading in the translation process that causes gene expression errors (Brégeon et al 2001) modification of this tRNA is believed to have an important role in the process of antimicrobial resistance and the persistent nature of $A$. baumannii in biofilms (Cabral et al 2011).

Fig. 1 shows that there appears to be an up-regulation of proteins involved in histidine metabolism, including CarO and HutU (urocanase). CarO is a protein in the outer membrane of $A$. baumannii and together with OmpA acts as a channel for the entry of L-His into bacterial cells (Cabral et al 2011). Urocanase is an enzyme that plays an important role in L-His degradation in histidine metabolism with purine and pyrimidine end results (Kapatral et al 2004). Purine and pyrimidine are the raw materials for eDNA biosynthesis, where eDNA is an important component in biofilm matrices with EPS and other proteins (Cabral et al 2011).

In addition to stimulating biofilms, an increase in exogenous levels of glucose increases the expression of genes involved in the production of LPS (Lipopolysaccharide) A. baumannii. In Rossi et al's study, it was shown that the increase in LPS production in media added to glucose with levels of $0.08 \%, 0.15 \%$ and $0.2 \%$ (Rossi et al 2016). LPS is an important characteristic of Gram negative bacteria and is a ligand for Toll-like receptors 4 (TLR4). LPS A. baumannii does not contain O-antigen, similar to LPS in Neisseria and Campylobacter species, so the LPS has a LOS 
(Lipo-Oligosaccharide) design (Luke et al 2010). LPS can be released from the bacterial cell wall into the host bloodstream in the form of a monomer (Mattsby-Baltzer et al 1991) or as OMV (Outer Vesicle Membrane) (Beveridge 1999). Secretion of A. baumannii LPS as OMV contributes to virulence factors ( $\mathrm{Li}$ et al 2015) and is a strong inducer of macrophage cytokine production in experimental animals. Increased production of LPS as a response to glucose induction is not directly related to the outer membrane biogenesis process and is not strongly bound to the surface of bacterial cells because it is easily released by rinsing EDTA. This provides an insight that A. baumannii in the blood will be induced to produce LPS, which has weak bonds on the surface of bacterial cells (Rossi et al 2016). If the nature of $A$. baumannii LPS is related to the ability of $A$. baumannii biofilm production on the surface of medical devices, especially IV-line catheters, then we need to be cautious if $A$. baumannii colonization is found in the device, which will produce easily released LPS following the flow blood and trigger a great increase in the production of host macrophage cytokines. LPS production in the blood and will increase up to 5 times or more in hyperglycemic sugar levels (>200 mg/dL) (Rossi et al 2016).

\section{CONCLUSION}

Biofilm density of clinical isolates of A. baumannii patients in ICU of Dr. Soetomo Hosspital, Surabaya, induced with glucose concentration $0.08 \%$; $0.015 \%$; $0.2 \% ; 0.4 \%$ has an OD630 average successively $0.137+$ $0.042 ; 0.272+0.124 ; 1.274+0.290 ; 3.407+0,269$. Biofilm density of clinical isolates of $A$. baumannii patients in ICU RSUD dr. Surabaya Soetomo which is not glucose induced has an OD630 average $0.126+$ 0.062. Biofilm density of clinical isolates of $A$. baumannii patients in ICU RSUD dr. Soetomo Surabaya significantly increased with glucose induction concentrations of $0.2 \%$ and $0.4 \%$.

\section{REFERENCES}

Amyes SGB, Young HK (1996). Mechanisms of antibiotic resistance in Acinetobacter spp. - genetics of resistance. Acinetobacter: Microbiology, Epidemiology, Infection, Management. New York, CRC Press, p 185-223

Anandhalakshmi S, Shasshikala N, Noyal MJ, Reba K (2017). Profile of multidrug resistant Acinetobacter baumannii infections among hospitalized patients. Journal of Medical Science and Clinical Research. V5i6, 23111-23115
Arisma BJN, Yunus M, Fanani E (2017). Gambaran pengetahuan masyarakat tentang resiko penyakit diabetes mellitus di kecamatan Pakisaji kabupaten Malang. Preventia. Available at http://www.journal. um.ac.id/index.php/preventia/article/view/10010/4753

Badave GK, Dhananjay K (2015). Biofilm producing multidrug resistant Acinetobacter baumannii: An emerging challenge. Journal of Clinical and Diagnostic Research 9, DC08-DC10

Bergogne-Bérézin E, Towner KJ (1996). Acinetobacter spp. as nosocomial pathogens: microbiological, clinical, and epidemiological features. Clin Microbiol Rev 9, 148-165

Beveridge TJ (1999). Structures of Gram-negative cell walls and their derived membrane vesicles. J. Bacteriol. 181, 4725-4733

Blanco N, Harris AD, Rock C, Johnson K, Pineles L, et al (2018). Risk factors and outcomes associated with multidrug-resistant Acinetobacter baumannii upon ICU admission. AAC. DOI: 10.1128/AAC.01631-17

Borer A, Gilad J, Smolyakov R, et al (2005). Cell phones and Acinetobacter transmission. Emerg Infect Dis 11, 1160-1161

Brégeon D, Colot V, Radman M, Taddei F (2001). Translational misreading: a tRNA modification counteracts a +2 ribosomal frameshift. Genes Dev. 15 , 2295-2306

Buisson Y, Nhieu, GT, Ginot L, Bouvet P, Shill H, Driot L, Meyran M (1990). Nosocomial outbreaks due to amikacin-resistant tobramycin sensitive Acinetobacter species: correlation with amikacin usage. J Hosp Infect 15, 83-93

Cabral MP, Soares NC, Aranda J, et al (2011). Proteomic and functional analyses reveal a unique lifestyle for Acinetobacter baumannii bioflms and a key role for histidine metabolism. J. Proteome Res. $10,3399-3417$

Costerton JW, Stewart PS, Greenberg EP (1999). Bacterial biofilms: a common cause of persistent infections. Science 284: 1318-1322

Costerton W, et al (2003). The application of biofilm science to the study and control of chronic bacterial infections. J Clin Invest 112, 1466-77

Cox RA (2004). Quantitative relationships for specifc growth rates and macromolecular compositions of Mycobacterium tuberculosis, Streptomyces coelicolor A3 (2) and Escherichia coli B/r: an integrative theoretical approach. Microbiology 150, 1413-1426

Dijkshoorn L, Nemec A, Seifert H (2007). An increasing threat in hospitals: multidrug-resistant Acinetobacter baumannii. Nat Rev Microbiol 5, 939951

Donlan RM, Costerton JW (2002). Biofilms: survival mechanisms of clinically relevant microorganisms. Clin Microbiol Rev 15, 167-193 
Donlan RM (2001). Biofilm formation: A clinically relevant microbiological process. Clinical Infectious Diseases 33, 1387-92

Fagon JY, Chastre J, Domart Y, Trouillet JL, Gibert C (1996). Mortality due to ventilator-associated pneumonia or colonization with Pseudomonas or Acinetobacter species: assessment by quantitative culture of samples obtained by a protected specimen brush. Clin Infect Dis 23, 538-542

Fani R, Brilli M, Fondi M, Lió P (2007). The role of gene fusions in the evolution of metabolic pathways: the histidine biosynthesis case. BMC Evol. Biol. 7, S4

Gaddy JA, Tomaras AP, Actis LA (2009). The Acinetobacter baumannii (19606) OmpA protein plays a role in biofilm formation on abiotic surfaces and the interaction of this pathogen with eukaryotic cells. Infect Immun 77, 3150-3160

Garnacho-Montero J, Sole-Violan J, Sa-Borges M, Diaz E, Rello J (2003). Clinical impact of pneumonia caused by Acinetobacter baumannii in intubated patients: a matched cohort study. Crit Care Med 31, 2478-2482

Giannouli M, Antunes LC, Marchetti V, Triassi M, Visca P, Zarrilli R (2013). Virulence-related traits of epidemic Acinetobacter baumannii strains belonging to the international clonal lineages I-III and to the emerging genotypes ST25 and ST78. BMC Infect Dis 13,282

Haryani S, Defrin, Yenita (2016). Prevalensi kanker serviks berdasarkan paritas di RSUP dr. M. Djamil Padang periode Januari 2011-Desember 2012. Jurnal Kesehatan Andalas 5, 647-652

Hsu LY, Apisarnthanarak A, Khan E, Suwantarat N, Ghafur A, Tambyah PA (2017). Carbapenem-resistant Acinetobacter baumannii and Enterobacteriaceae in South and Southeast Asia. Clinical Microbiology Revi. 30, 1-22

Joly-Guillou ML, Brun-Buisson C (1996). Epidemiology of Acinetobacter spp.: surveillance and management of outbreaks. AcinetobacterMicrobiology, Epidemiology, Infection, Management. New York, CRC Press, p 71-100

Joly-Guillou ML, Decre D, Herrman JL, Bourdelier E, Bergogne-Berezin E (1995). Bactericidal in-vitro activity of $\beta$-lactams and $\beta$-lactamase inhibitors, alone or associated, against clinical strains of Acinetobacter baumannii: effect of combination with aminoglycosides. J Antimicrob Chemother 36, 619629

Kapatral V, Campbell JW, Minnich SA, Thomson NR, Matsumura P, Pr€uss, BM (2004). Gene arrays analysis of Yersinia enterocolitica FIhD and FIhC: regulation of enzymes affecting synthesis and degradation of carbamoylphosphate. Microbiology $150,2289-2300$
Khosama Y (2015). Faktor resiko kanker kolorektal. CDK 234 42, 829-832

Kitagawa K, Tateishi A, Nakano F, Matumoto I, Morohoshi I, Tanino T, Osui T (1986). Generation of energy coupled with membrane-bound glucose dehydrogenase in Acinetobacter calcoaceticus. Agric. Bioi. Chem. 50

Lambert T, Gerbaud G, Bouvet P, Vieu Jf, Courvalin P (1990). Dissemination of amikacin resistance gene aphA6 in Acinetobacter spp. Antimicrob Agents Chemother 34, 1244-1248

Lee JC, Koerten H, van den Broek P, et al (2006). Adherence of Acinetobacter baumannii strains to human bronchial epithelial cells. Res Microbiol 157, 360-366

Lee JS, Lee JC, Lee CM, Jung ID, Jeong YI, Seong EY, Chung HY, Park YM (2007). Outer membrane protein A of Acinetobacter baumannii induces differentiation of CD4+ $\mathrm{T}$ cells toward a Th1 polarizing phenotype through the activation of dendritic cells. Biochem Pharmacol 74, 86-97

Li ZT, Zhang RL, Bi XG, et al (2015). Outer membrane vesicles isolated from two clinical Acinetobacter baumannii strains exhibit different toxicity and proteome characteristics. Microb. Pathog. 81, 46-52

Longo F, Vuotto C, Donelli G (2014). Biofilm formation in Acinetobacter baumannii. New Microbiologica 37, 119-127

Luke NR, Sauberan, SL, Russo TA, et al (2010). Identifcation \& characterization of a glycosyltransferase involved in Acinetobacter baumannii lipopolysaccharide core biosynthesis. Infect. Immun. 78, 2017-2023

Mattsby-Baltzer I, Lindgren K, Lindholm B, Edebo L (1991). Endotoxin shedding by enterobacteria: free and cell-bound endotoxin differ in Limulus activity. Infect. Immun. 59, 689-695

McConnell MJ, Actis L, Pachon J (2013). Acinetobacter baumannii: human infections, factors contributing to pathogenesis and animal models. FEMS Microbiol Rev 37, 130-155

Mewo MES (2017). Pengaruh induksi glukosa terhadap pembentukan biofilm isolat klinis Acinetobacter baumannii dari urine kateter indwelling pasien non diabetes mellitus. Surabaya, Faculty of Medicine, Universitas Airlangga

Mussi MA, Limansky AS, Viale AM (2005). Acquisition of resistance to carbapenems in multidrug-resistant clinical strains of Acinetobacter baumannii: natural insertional inactivation of a gene encoding a member of a novel family of b-barrel outer membrane proteins. Antimicrob Agents Chemother 49, 1432-1440

Neely AN, Maley MP, Warden GD (1999). Computer keyboards as reservoirs for Acinetobacter baumannii in a burn hospital. Clin Infect Dis 29, 1358-1360 
Neely AN (2000). A survey of gram-negative bacteria survival on hospital fabrics and plastics. J Burn Care Rehabil 21, 523-527

NICE Guidelines. (2004. Type 1 diabetes: diagnose \& manangement of type 1 diabetes in children, young people and adults. NICE Clinical Guideline 15. Available at http://www.nice.org.uk/guidance/CG15, http://www.nice.org.uk/guidance/CG66. Accessed July 18, 2018

Roca I, Espinal P, Vila-Farres X, Vila J (2012). The Acinetobacter baumannii oxymoron: commensal hospital dweller turned pan-drug-resistant menace. Front Microbiol 3, 148

Rossi E, Longo F, Barbagallo M, Peano C, Consolandi C, Pietrelli A, Jaillon S, Garlanda C, Landini P (2016). Glucose aviability enhances lipopolysaccharide production and immunogenicity ini opportunistic pathogen Acinetobacter baumannii. Future Microbiology Ltd. DOI: 10.2217/FMB.15.153

Safari M, Nejad ASM, Bahador A, Jafari R, AlikhanI MY (2015). Prevalence of ESBL and MBL encoding genes in Acinetobacter baumannii strains isolated from patients of intensive care units (ICU). Saudi journal of biological sciences 22, 424-9

Seifert H, Strate A, Pulverer G (1995). Nosocomial bacteremia due to Acinetobacter baumannii. Clinical features, epidemiology, and predictors of mortality. Medicine 74, 340-349

Shin JB, Lee HW, Kim SM, Kim J (2009). Proteomic analysis of Acinetobacter baumannii in biofilm and planktonic growth mode. J. Microbiol 47, 728-735

Sukanya S, Lakshmi V, Padmaja K (2014). Prevalence of multidrug resistant Acinetobacter baumannii in clinical samples in a tertiary care hospital. Int $\mathbf{J}$ Infect Control V11, i3

Talbot GH, Bradley J, Edwards JE, Jr, Gilbert D, Scheld M, Bartlett JG (2006). Antimicrobial Availability Task Force of the Infectious Diseases Society of America: Bad bugs need drugs: an update on the development pipeline from the Antimicrobial Availability Task Force of the Infectious Diseases Society of America. Clin Infect Dis 42, 657-668

Towner KJ, Bergogne-Bérézin E, Fewson CA (1991). Acinetobacter: Portrait of a genus. The biology of
Acinetobacter: taxonomy, clinical importance, molecular biology, physiology, industrial relevance. FEMS Symposium 57, 1-24

Towner KJ (2009). Acinetobacter: an old friend, but a new enemy. J Hosp Infect 73, 355-363

Trautner BW, Darouiche RO (2004). Role of biofilm in catheter associated urinary tract infections. Am. J. Infect. Control 32, 177-83

Vijayakumar S, Rajenderan S, Laishram S, Anandan S, Balaji V, Biswas I (2016). Biofilm formation and motility depend on the nature of the Acinetobacter baumannii Clinical Isolates. Front Public Health 4, 105

Vila J, Marcos A, Marco F, Abdalla S, Bergara Y, Reig R, Gomez-Lus R, Jimenez de Anta T (1993). In vitro antimicrobial production of $\beta$-lactamases, aminoglycosidemodifying enzymes, and chloramphenicol acetyltransferase by and susceptibility of clinical isolates of Acinetobacter baumannii. Antimicrob Agents Chemother 37, 138141

Villegas MV, Hartstein AI (2003). Acinetobacter outbreaks, 1977-2000. Infect Control Hosp Epidemiol 24, 284-295

Wisplinghoff H, Perbix W, Seifert H (1999). Risk factors for nosocomial bloodstream infections due to Acinetobacter baumannii: a case-control study of adult burn patients. Clin Infect Dis 28, 59-66

Wisplinghoff $\mathrm{H}$, Bischoff $\mathrm{T}$, Tallent SM, Seifert $\mathrm{H}$, Wenzel RP, Edmond MB (2004). Nosocomial bloodstream infections in US hospitals: analysis of 24,179 cases from a prospective nationwide surveillance study. Clin Infect Dis 39, 309-317

Yanong I, Ramli S, Widodo ADW, Wasito EB (2017). Pola kepekaan antibiotika Acinetobacter baumannii dari spesimen sputum di RSUD dr. Soetomo Surabaya Periode Januari 2017-Juni 2017. Pertemuan Ilmiah Tahunan Persatuan Ahli Mikrobiologi Klinik Padang Tahun 2017

Zarrilli R (2016). Acinetobacter baumannii virulence determinants involved in biofilm growth and adherence to host epithelial cells. Virulence 7, 367368. DOI: $10.1080 / 21505594.2016 .1150405$ 